Article

\title{
The Influence of Allocation on the Carbon Footprint of Electricity Production from Waste Gas, a Case Study for Blast Furnace Gas
}

\author{
Maarten Messagie ${ }^{1}{ }^{*}$, Fayçal Boureima ${ }^{1}$, Jan Mertens ${ }^{2}$, Javier Sanfelix ${ }^{1}$, Cathy Macharis ${ }^{1}$ \\ and Joeri Van Mierlo ${ }^{1}$
}

1 Mobility and Automotive Technology Research Group (MOBI), Faculty of Engineering, Vrije Universiteit Brussel, Pleinlaan 2, Brussels 1050, Belgium; E-Mails: fboureim@vub.ac.be (F.B.); jsanfeli@vub.ac.be (J.S.); cathy.macharis@vub.ac.be (C.M.); joeri.van.mierlo@vub.ac.be (J.V.M.)

2 Laborelec, Rodestraat 125, Linkebeek 1630, Belgium; E-Mail: jan.mertens@laborelec.com

* Author to whom correspondence should be addressed; E-Mail: maarten.messagie@ vub.ac.be; Tel.: +32-2-629-2839; Fax: +32-2-629-3620.

Received: 14 December 2012; in revised form: 19 February 2013 / Accepted: 22 February 2013 / Published: 1 March 2013

\begin{abstract}
Producing electricity from waste gas is an after treatment for waste gas while recovering the energy content. This paper addresses the methodology to calculate the effect that waste gas energy recovery has on lowering the impact of climate change. Greenhouse gases are emitted while burning the waste gas. However, a thorough study should include the production of the feedstock as well as the production of the infrastructure. A framework is developed to calculate the environmental impact of electricity production from waste gas with a life cycle approach. The present paper has a twofold purpose: to assess the climate change impact of generating electricity with blast furnace gas (BFG) as a waste gas from the steel industry; and to establish a sensitivity assessment of the environmental implications of different allocation rules.
\end{abstract}

Keywords: life cycle assessment; waste gas; blast furnace gas; allocation

\section{Introduction}

When products or processes are developed and optimized it is important to include their environmental performance in the decision process. Life Cycle Assessment (LCA) is a methodology which allows 
giving a complete and unbiased environmental impact of a product or service; it is, furthermore, the most prevailing methodology to do so. LCA assesses the overall environmental impact of a product or service by including all direct and indirect impacts of all life phases of the product or service from "cradle-to-grave" (mining of resources, production, distribution, use phase and end of life treatment). When computing the inventory data, the LCA practitioner sometimes needs to share the emissions from multi-output processes between their different products. This portioning operation is called allocation. In the ISO 14044:2006 standard [1], a procedure has been developed in order to guide the LCA practitioner to deal with a multi-output process. Methodological studies have identified procedures to deal with allocation [2-13]. All of them recognize the importance of allocation procedures on the end result and on the decision that will be based on the result of a LCA study. This paper assesses the carbon footprint of generating electricity with blast furnace gas (BFG) as a waste gas from the steel industry; and establishes a sensitivity assessment of the environmental implications of different allocation rules. The paper shows a carbon footprint calculation, which is a LCA exercise limited only to the emissions that have an effect on climate change. Carbon dioxide $\left(\mathrm{CO}_{2}\right)$, methane $\left(\mathrm{CH}_{4}\right)$ and nitrous oxide $\left(\mathrm{N}_{2} \mathrm{O}\right)$ are taken into consideration in the model as they are the most important greenhouse gases. The study focuses on climate change only as it is among the most relevant impact categories for the energy and steel sector. However, the provided allocation procedures are general applicable and can be used to calculate impacts on other relevant impact categories such as human health, ecosystem quality and resource depletion. Moreover the allocation rules can be used in other multi-functional processes. The study includes emissions related to the building of the infrastructure, the fuel supply chain and the conversion emissions in the electricity plant. Some case studies have shown that allocation rules can have an influence on the calculated impact of bioenergy on the environment [14-28]. According to Cherubini et al. [29] allocation is important in the bio-energy context because bioenergy systems are often part of multifunctional processes. Electricity production from waste streams is also composed of multifunctional processes, making it worthwhile to investigate allocation procedures and their influences on the environment more in detail. The different allocation rules to produce electricity from waste gases are compared on the same functional unit (FU). The FU is a quantified description of the performance of a product system. The FU is used as a reference unit. It allows comparing two or several product systems on the basis of a common provided service. Every LCA study includes a FU that defines what is being studied and it is based on the goal and scope definitions. The use of a FU allows the comparison between other different LCA studies. As a consequence, all the end results of a LCA are related to the described FU and do not reflect the overall absolute impact of a product system. In this case, the production of $1 \mathrm{kWh}$ of electricity has been chosen as the functional unit. In order to create a methodological framework for the practice of LCA on one hand and to ensure that all requirements of the methodologies are met, the International Standardization Organization (ISO) has published two standards, the ISO 14040:2006 [30] and the ISO 14044:2006 [1].

\section{Theoretical Framework}

Life Cycle Assessment is described as the evaluation of the material and energy flows alongside with their induced environmental stress throughout the life cycle of a product or service. This group of 
materials and energy pathways are called the elementary flows and are gathered in a life cycle inventory (LCI). The life cycle of a product is modeled as a system consisting of several other sub-systems; they resemble the activities throughout the different steps in the life cycle. The system is modeled from cradle-to-grave, which is from material production (cradle) to the final end-of-life treatment of the product (grave).

A LCI modeling problem arises when one of the functions of the product system is composed of a multifunctional process and the other is used in another product system. The LCI modeling problem that exists is the choice on how to divide or allocate the environmental impacts from the multifunctional process to the different product systems. The allocated share of the environmental burden of the multifunctional process to the product system under study significantly influences the result of the LCA. A large number of methodological approaches and solutions were developed in the past to deal with this issue of allocation. The ISO 14044:2006 norm includes a procedure to deal with the allocation problem in LCA [1]:

- Avoid allocation by dividing the multi-output processes in individual sub-processes and collect data for the sub-processes.

- Avoid allocation with an expansion of the system and attribute to the product-system a credit equivalent to the production of co-products elsewhere.

- However, when the allocation cannot be avoided, the inputs and outputs should be partitioned between the different co-products with respect to the physical and quantitative relationship between inputs/outputs and co-products.

- Sometimes, physical relationship could not be established between inputs/outputs and the co-products. In such a case, other relationship, e.g., the unit price might be used as a basis for allocation.

Figure 1 explains the allocation procedure [31]. The multi-output process delivers two jointly produced products, products 1 and 2 . The problem that arises is how to allocate the emissions from the multi-output process between products 1 and 2. It is considered that product 1 is the product under investigation in the LCA. If the multi-output process consists out of two separate sub-processes (sub-processes 1 and 2) and if separated emission data exists, it is possible to avoid allocation by subdivision. Because of this specific procedure, the LCA of product 1 should take only the emissions from sub-process 1 into account. The allocation problem is eliminated if it is possible to subdivide the multi-output process in single-output processes. However, in many multi-output processes it is not possible to split-up the joint production as there is no physically separation of sub-processes. In this case, to avoid allocation, an expansion of the system can be an option. In system expansion the boundaries of the LCA are expanded in order to include processes that are influenced by the product under investigation. The multi-output process produces product 1 and hereby avoids the alternative production of product 1 . The avoidance of the alternative production and its' related emissions can be credited to the multi-output process. When system expansion is not an option, the allocation of the emissions of the multi-output process can be based on relationships between the products 1 and 2 such as price, weight, volume, exergy and energy content. In this paper five different approaches are discussed to deal with the multifunctional process: system expansion, industry split-up, economic, exergetic and energetic allocation. 
Figure 1. Overview of the allocation problem in multi-output processes.

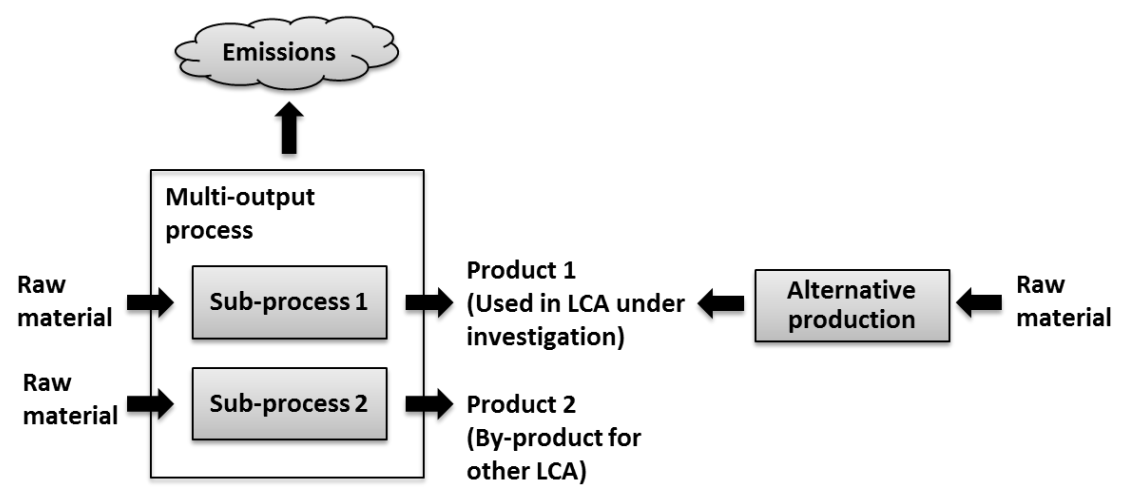

\section{The Blast Furnace Gas Case}

When producing electricity from blast furnace gas, two allocation problems coexist; one related to the conversion process and one related to the feedstock production. During the conversion step (right part of Figure 2) the production of the electricity from blast furnace gas is seen as a multi-output process with two functions: producing electricity and treating the blast furnace gas, which is a waste from the steel industry. Which part of the downstream emissions should be allocated to the electricity production and which part should be allocated to the fact that the electricity plant is treating the waste gas from the steel industry? During the blast furnace process (left part of Figure 2) the question is how to allocate the upstream emissions between the two output products: the pig iron and the blast furnace gas. Combining the "feedstock" and the "conversion" allocation rules provide different sets of results. The blast furnace process uses coke, coal, blast furnace gas, coke oven gas, natural gas and iron ore to produce pig iron. The blast furnace gas, mainly composed of carbon monoxide, is an emission that occurs during this process. The blast furnace gas is recycled partly by the blast furnace process itself as it has an energetic value; the rest can be flared in order to oxidize the toxic carbon monoxide into non-toxic $\mathrm{CO}_{2}$. However, a different strategy is that instead of flaring the blast furnace gas, it can be diverted and used to produce electricity. Therefore the blast furnace gas replaces a share of natural gas.

Figure 2. Overview of the allocation problem that arises from producing electricity with blast furnace gas as a waste gas.

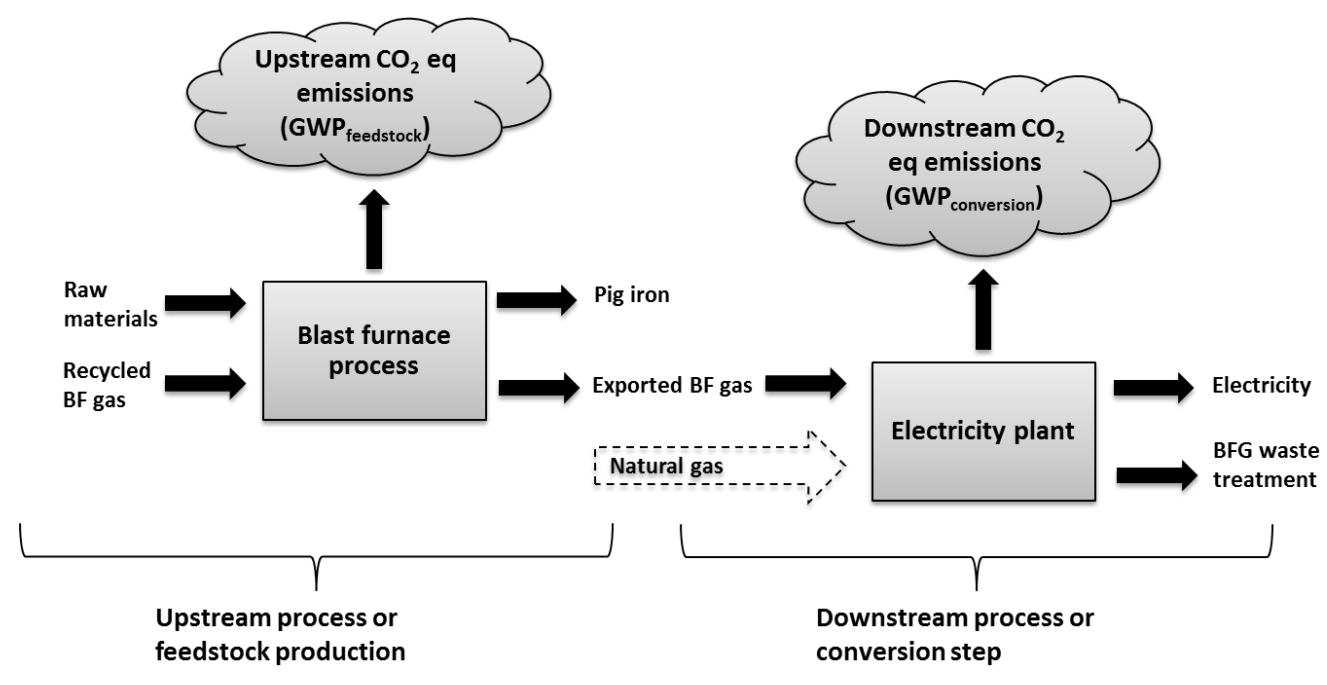




\subsection{System Expansion}

As the production of blast furnace gas is a consequence of the pig iron production, it is not possible to avoid allocation by splitting up the multi-output process in two separated sub-processes. However, it is still possible to avoid allocation via system expansion. When expanding the system it is possible to attribute credits to the product system (pig iron) equivalent to the production of the co-product (blast furnace gas) that is replacing the production of the alternative product (natural gas). As shown in Figure 2, the exported blast furnace gas is replacing natural gas. In studies dealing with system expansion of energy recuperation from waste streams it is mostly assumed that the waste stream is avoiding other energy sources [32-34]. In this sense, the production of pig iron should get a credit for offsetting the life cycle emissions originated while producing electricity from natural gas. The life cycle emissions for electricity generation from natural gas contain both the feedstock production, distribution and the conversion emissions generated by the burning of natural gas in an electricity plant. The life cycle impact of the pig iron includes all the upstream blast furnace emissions minus the production of the natural gas and all the downstream emissions during the conversion step in the electricity plant, without the emissions from producing an equivalent amount of electricity with natural gas. The blast furnace process is getting the benefit of recovering the energy content of the waste gas. The impact of producing electricity from blast furnace gas is equivalent to producing electricity from natural gas, in order to keep the whole system at an equivalent status.

\subsection{Industry Split up}

In the EU Emissions Trading System (EU-ETS) [35] waste gases are defined as gases derived from incomplete combustion or chemical reactions. Waste gases are not emitted without further combustion, because of the high content of incomplete or non-oxidized carbon that can be used in another process. The emissions occurring during the production of the waste gas are fully allocated to its producer (in this particular case the steel industry) according to the EU-ETS regulation. The consumer of the waste gas, the electricity producer, receives no additional allocation for the production of the feedstock (the blast furnace gas). Referring to Figure 2, the upstream emissions are fully allocated to the pig iron. The part of the blast furnace gas which is exported to the electricity plant, does not share the burden of the upstream emissions. On the other hand, if the waste gas is used to produce electricity the consumer of the waste gas is fully allocated with the conversion emissions occurring in the electricity plant. The downstream emissions from Figure 2 are fully allocated to the production of the electricity. The steel producer receives no emissions for the 'waste treatment' process, carried out by the electricity producer. Summarizing, the emissions from both industries are split up, the emissions occurring in each industry's own processes are fully allocated to their intended output product. For the steel industry this is the production of pig iron, for the electricity producer this is the production of electricity. There is no transfer of up- or downstream responsibilities and related emissions.

\subsection{Economic Allocation}

Another way to allocate the upstream $\mathrm{CO}_{2}$ emissions to the two co-products (pig iron and $\mathrm{BFG}$ ) is by means of an economic allocation. As the electricity production is using the blast furnace gas as an 
input, it can be argued that a partition of the upstream emissions should be allocated to the electricity producer. One way to allocate the $\mathrm{CO}_{2}$ emissions is with a price based share. The economic allocation rule makes sense as the reason for the upstream emissions is ultimately the production of steel and the fact that the steel producers wants to create a financial profit. All the inputs and outputs involved in the production of $1 \mathrm{~kg}$ of pig iron are described in Figure 3. In the left side (input), the different energy carriers, materials and their respective amounts (involved in the production of $1 \mathrm{~kg}$ of pig iron) are given. On the right side (output), the emissions of $\mathrm{CO}, \mathrm{CO}_{2}$ and $\mathrm{BFG}$ induced by the production of $1 \mathrm{~kg}$ of pig iron are given. As it can be noticed, the production of $1 \mathrm{~kg}$ of pig iron generates $1.6 \mathrm{Nm}^{3} \mathrm{of}$ BFG. However $0.9 \mathrm{Nm}^{3}$ of $\mathrm{BFG}$ is recycled through the blast furnace and finally, only $0.7 \mathrm{Nm}^{3}$ of $\mathrm{BFG}$ are exported to the electricity producer [36].

Figure 3. The balance of a blast furnace process.

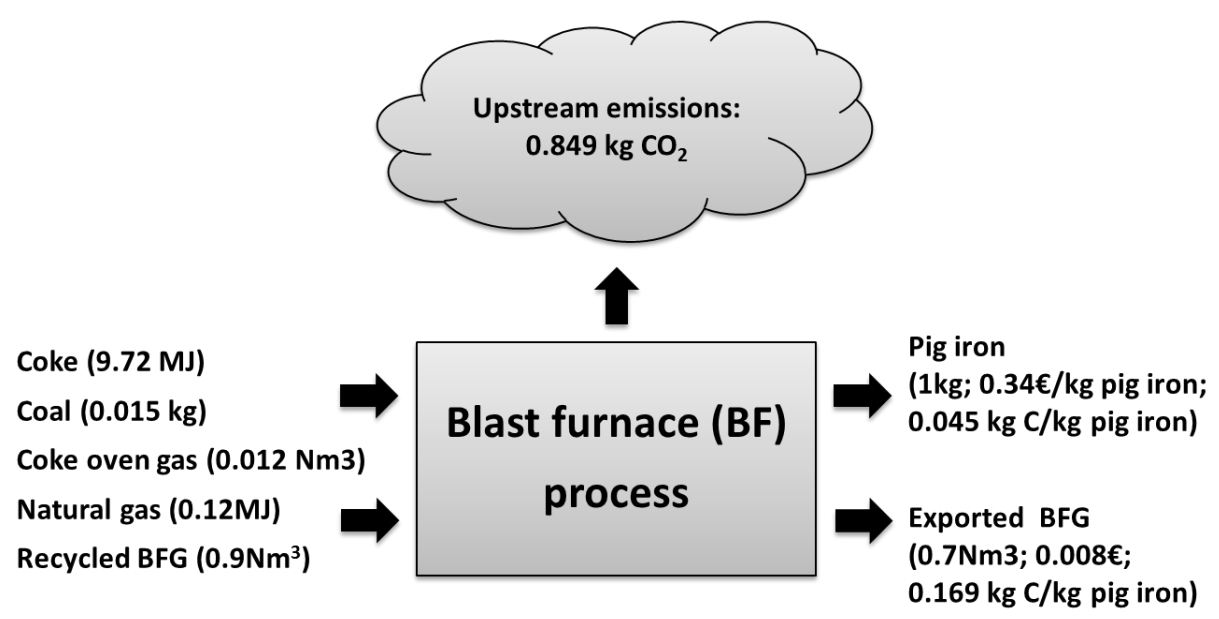

The unit price of BFG on the Belgian market is assumed to be $3.1 € / G J$ and its Lower Heating Value (LHV) is $3.67 \mathrm{MJ} / \mathrm{Nm}^{3}$. The unit price of pig iron on the international market is assumed to be $465 \$ /$ ton or $0.34 € / \mathrm{kg}$ of pig iron [37]. The final price of the amount of BFG involved in the production of $1 \mathrm{~kg}$ of pig iron is then calculated. The net amount of $\mathrm{BFG}\left(\mathrm{Nm}^{3}\right)$ produced per $\mathrm{kg}$ of BFG is multiplied by the LHV $\left(\mathrm{MJ} / \mathrm{Nm}^{3}\right)$ of the $\mathrm{BFG}$ in order to obtain the energy content. Later, the energy content is then converted in GJ and multiplied by the unit price of the BFG ( $€ / G J)$. The economic allocation factors of the BFG and the pig iron are then calculated. The $\mathrm{CO}_{2}$ emissions allocated to the BFG will represent $2.3 \%$ of the emissions of the blast furnace process, Equation (2):

$$
\begin{gathered}
\text { Cost }_{B F G}=\left(0.7 \mathrm{Nm}^{3} \times \frac{\mathrm{MJ}}{\mathrm{Nm}^{3}} \times 1000\right) \times 3.1 \frac{€}{\mathrm{GJ}}=7.96 \times 10^{-3} € \\
\text { Factor }_{B F G}=\frac{\text { Cost }_{B F G}}{\left(\text { Cost }_{B F G}+\text { Cost }_{\text {Pig Iron }}\right)}=0.023=2.3 \%
\end{gathered}
$$

\subsection{Energetic Allocation}

As BFG is a waste product from the steel industry, it can be argued that the steel industry should receive a part of the downstream emissions described in Figure 2. The steel industry forces the electricity producer to use carbon monoxide as a fuel. This "conversion" allocation method is based on the chemical reactions and the corresponding energy which is released during the two sequential 
reactions: oxidizing $\mathrm{C}$ to $\mathrm{CO}$ (steel industry) and oxidizing $\mathrm{CO}$ to $\mathrm{CO}_{2}$ (electricity producer). The final $\mathrm{CO}_{2}$ emissions are created since the steel industry and the electricity producer both needed the oxidation energy in the two steps. The energetic allocation will divide the final $\mathrm{CO}_{2}$ emissions according to the energy released in the two steps. During the first step, the steel industry uses the energy released during the oxidization of carbon in carbon monoxide, when carbon reacts to carbon monoxide, $110 \mathrm{~kJ} / \mathrm{mol}$ is released. During the second part, the electricity producer uses the energy released when carbon monoxide is evolving further to carbon dioxide. During the reaction of carbon monoxide to carbon dioxide, $283 \mathrm{~kJ} / \mathrm{mol}$ is released. The full reaction of carbon oxidizing to $\mathrm{CO}_{2}$ releases $393 \mathrm{~kJ} / \mathrm{mol}$. A share of $72 \%(283 \div 393)$ of the total energy originates from the oxidization process of $\mathrm{CO}$ to $\mathrm{CO}_{2}$. As a consequence, $72 \%$ of the carbon dioxide released during the combustion of $\mathrm{CO}$ in the electricity plant is allocated to the electricity production; the other part is allocated to the steel production as an impact associated for the "waste treatment".

\subsection{Exergetic Allocation}

Another way to allocate the emissions is with an exergetic allocation rule. The exergetic allocation rule applies to the full system and includes both industries. The multi-functional process produces pig iron as well as electricity, see Figure 4. The total carbon emissions from the steel industry and the electricity producer will be divided taken the exergy of both products (pig iron and electricity) into consideration.

Figure 4. Overview of the exergetic allocation rule for pig iron and electricity produced in a blast furnace process.

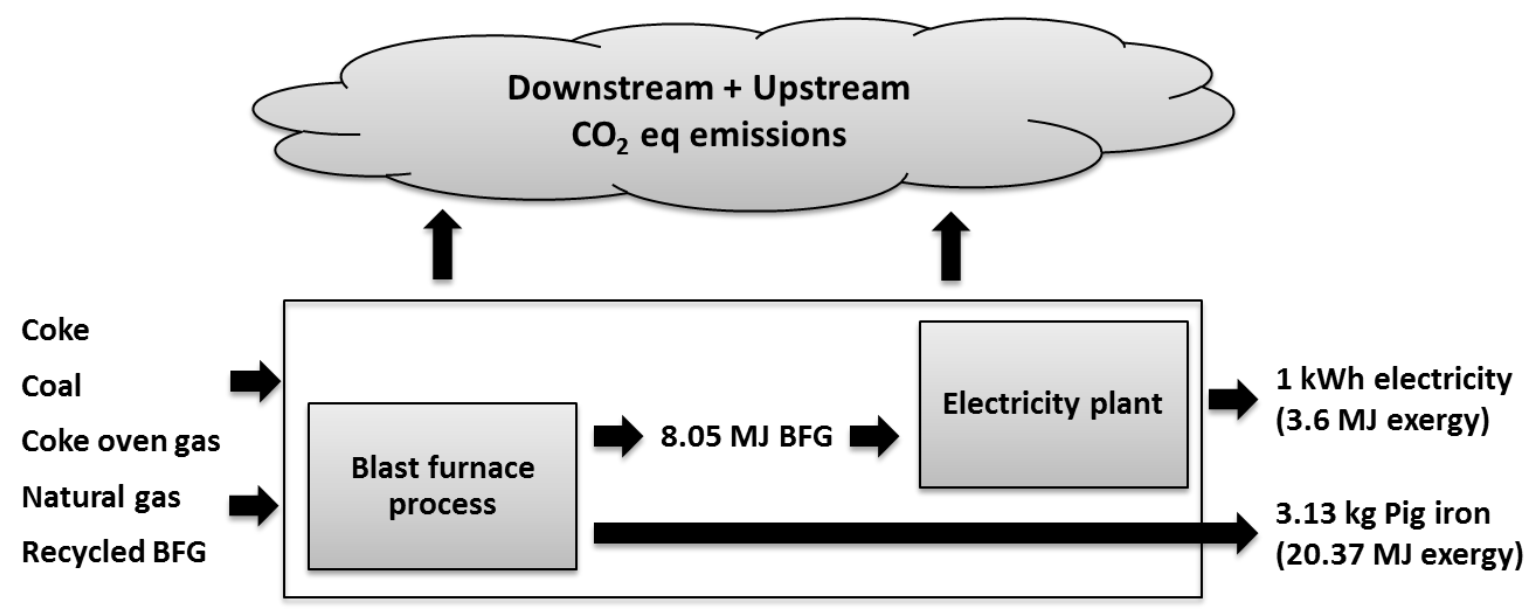

To produce $1 \mathrm{kWh}$ of electricity $8.05 \mathrm{MJ}$ BFG is needed. To produce $1 \mathrm{~kg}$ of steel, $2.56 \mathrm{MJ}$ of BFG (3.67 MJ/ $\mathrm{Nm}^{3} \times 0.7 \mathrm{Nm}^{3}$ ) is exported to the electricity plant. This means that for every $\mathrm{kWh}$ electricity, $3.13 \mathrm{~kg}$ of pig iron is produced. The exergy of $1 \mathrm{kWh}$ electricity is $3.6 \mathrm{MJ}$. According to Gasparatos $1 \mathrm{~kg}$ of pig iron corresponds to $6.57 \mathrm{MJ}$ exergy [38]. When producing $1 \mathrm{kWh}$ of electricity, 20.37 MJ pig iron is produced. The downstream and upstream carbon emissions are divided over the co-products taking the exergy content into consideration. This means that $85 \%$ of the total emissions are allocated to the production of pig iron and the remaining $15 \%$ of the emissions are allocated to the production of electricity. 


\section{Life Cycle Inventory}

\subsection{Conversion}

The conversion $\mathrm{CO}_{2}$ emissions are measured by the electricity producer, together with the fuel consumption and the electricity production. However, these emissions should be treated with caution as they also contain $\mathrm{CO}_{2}$ emissions from the blast furnace process. All the $\mathrm{CO}_{2}$ emissions which enter the electricity plant via the composition of the blast furnace gas are inert during the combustion and will not add energy to the process. This part of the $\mathrm{CO}_{2}$ is therefore considered as $100 \%$ allocated to the blast furnace. The remaining $\mathrm{CO}_{2}$ equivalent conversion emissions are $1.102 \mathrm{~kg} \mathrm{CO} 2 \mathrm{eq} / \mathrm{kWh}$ for electricity produced with blast furnace gas and $0.358 \mathrm{~kg} \mathrm{CO}_{2} \mathrm{eq} / \mathrm{kWh}$ for the production of electricity with natural gas (these values were directly obtained from the electricity producer). The $\mathrm{CO}_{2}$ equivalent emissions include both methane and nitrous oxide emissions, as these two pollutants have an effect on climate change. The conversion emissions from producing electricity with natural gas are gathered for the modeling of the "system expansion" case.

\subsection{Impacts of the Construction of the Power Plants}

For the impacts of the production and the decommissioning of the power plant, default EcoInvent data (Table 1) are considered for natural gas and blast furnace gas as they are combusted in the same plants. The EcoInvent datasets [39] on the power plant includes the land transformation and occupation, use of materials (concrete, steel, copper, plastics, etc. energy consumption, heat waste and the transport. In Table 1 the lifetime, the employment rate and the efficiency are taken into account in the calculation. The impact of these power plants originates essentially from the construction materials (gravel, cement, water, steel, explosives, etc.).

Table 1. EcoInvent assumptions on different power plant infrastructures [39].

\begin{tabular}{cccc}
\hline Name & EcoInvent process & Amount/kWh & CO $_{2} / \mathbf{k W h}$ \\
\hline Blast furnace gas plant & Gas power plant, 100 MWe/RER/I U & $7.28 \times 10^{-11}$ & $3.50 \times 10^{-4}$ \\
Natural gas plant & Gas power plant, 100 MWe/RER/I U & $5.95 \times 10^{-4}$ & $2.86 \times 10^{-4}$ \\
\hline
\end{tabular}

\subsection{Feedstock Production}

\subsubsection{Blast Furnace Gas Production}

The pig iron production process is used to model the feedstock production of BFG. All the inputs and outputs involved in the production of $1 \mathrm{~kg}$ of pig iron are considered. The production of pig iron is modeled with the Econinvent process "Pig iron, at plant/GLO U [kg] (\#1132)". As an input, we have the different energy carriers and materials as well as their amounts involved in the production of $1 \mathrm{~kg}$ of pig iron. The $\mathrm{CO}_{2}$ emissions and BFG are the described output. As it can be noticed, the production of $1 \mathrm{~kg}$ of pig iron generates $1.6 \mathrm{Nm}^{3}$ of BFG. However, $0.9 \mathrm{Nm}^{3}$ of $\mathrm{BFG}$ is recycled in the blast furnace and, only $0.7 \mathrm{Nm}^{3}$ of BFG is exported to the electricity producer. The lower heating value is $3.67 \mathrm{MJ} / \mathrm{Nm}^{3}$ [39]. When simultaneous producing $1 \mathrm{~kg}$ of pig iron and $0.7 \mathrm{Nm}^{3} \mathrm{BFG}, 1.56 \mathrm{~kg} \mathrm{CO}_{2} \mathrm{eq}$ is 
emitted [39]. This means that for $1 \mathrm{MJ}$ of $\mathrm{BFG}, 0.61 \mathrm{~kg} \mathrm{CO} \mathrm{CO}_{2} \mathrm{eq}$ is emitted in total according to Equation (3):

$$
0.61 \frac{\mathrm{kg} \mathrm{CO}_{2} \mathrm{eq}}{\mathrm{MJ} \mathrm{BFG}}=\frac{\left(1.56 \frac{\mathrm{kg} \mathrm{CO}}{\mathrm{kg} \text { pig iron }}\right)}{\left(0.7 \frac{\mathrm{Nm}^{3} \mathrm{BFG}}{\mathrm{kg} \mathrm{pig} \mathrm{iron}}\right)\left(3.67 \frac{\mathrm{MJ} \mathrm{BFG}}{\mathrm{Nm}^{3}}\right)}
$$

However, according to the economic allocation factor calculated with Equation (2), only $2.3 \%$ of the total $\mathrm{CO}_{2}$ of the blast furnace process emissions should be allocated to the production of BFG, the rest should be allocated to the pig iron production. The impact on climate change of producing BFG is $0.014 \mathrm{~kg} \mathrm{CO}{ }_{2} \mathrm{eq} / \mathrm{MJ}$ BFG, Equation (4). According to measurements done by the electricity producer, 8.05 MJ of BFG is needed to produce $1 \mathrm{kWh}$ of electricity. This means that $0.112 \mathrm{~kg} \mathrm{CO}_{2} \mathrm{eq}$ is emitted when producing the amount of BFG that is needed to generate $1 \mathrm{kWh}$ of electricity, Equation (5):

$$
\begin{gathered}
0.014 \frac{\mathrm{kg} \mathrm{CO}_{2} \mathrm{eq}}{\mathrm{MJBFG}}=2.3 \% \times 0.61 \frac{\mathrm{kg} \mathrm{CO}_{2} \mathrm{eq}}{\mathrm{MJ} \mathrm{BFG}} \\
0.112 \frac{\mathrm{kg} \mathrm{CO}_{2} \mathrm{eq}}{\mathrm{kWh}}=8.05 \frac{\mathrm{MJ} \mathrm{BFG}}{\mathrm{kWh}} \times 0.014 \frac{\mathrm{kg} \mathrm{CO}_{2} \mathrm{eq}}{\mathrm{MJ} \mathrm{BFG}}
\end{gathered}
$$

\subsubsection{Natural Gas Supply Mix}

For the natural gas production and transport, the Belgian situation is considered. The different type of natural gas per supplying country and their share in the Belgian mix are considered (Table 2). The country specific production and transport (to Europe) emissions are used to calculate the emissions of $1 \mathrm{MJ}$ of a Belgian supply mix natural gas. A lower heating value (LHV) of $37 \mathrm{MJ} / \mathrm{Nm}^{3}$ is considered.

The Qatari natural gas, which represents $17 \%$ of the Belgian supply mix, is modeled separately. In fact, it is supplied in a liquefied form and requires dedicated liquefaction and transport infrastructures. The liquefied natural gas (LNG) model includes the natural gas production, the liquefaction energy, the evaporation energy and the transport, see table 3. Since no specific inventory data from the natural gas extraction Qatar is available, the EcoInvent datasets corresponding to the extraction and the liquefaction of Algerian natural gas are applied. Transoceanic shipping over a distance of 6277 nautic miles is considered for the transport of the LNG between the Ras Laffan port in Qatar and Zeebrugge in Belgium. Once in Belgium, the LNG is evaporated in a decompression plant modeled according to the operation of an equivalent Italian plant [39]. The distribution of the natural gas to the end user after the evaporation is modeled according to the EcoInvent dataset including energy requirements, emissions and infrastructure of the high pressure distribution network in Belgium. The assessment of the different types of natural gas shows that the Qatari gas (LNG) is responsible of more than $51 \%$ of the overall GWP of the Belgian natural gas supply mix while it represents only $17 \%$ of the volume of the imports. This is due essentially to the liquefaction and the transport of the LNG which represents respectively $46 \%$ and $28 \%$ of the $\mathrm{CO}_{2}$ emissions of the $\mathrm{LNG}$. 
Table 2. Natural gas supply mix in Belgium [40].

\begin{tabular}{cccc}
\hline Country of origin & $\%$ & EcoInvent processes & kg CO $\mathbf{e q} / \mathbf{M J}$ \\
\hline Netherlands & 35 & Natural gas, production NL, at long-distance pipeline/RER U & $1.88 \times 10^{-3}$ \\
Norway & 35 & Natural gas, production NO, at long-distance pipeline/RER U & $3.64 \times 10^{-3}$ \\
UK & 4 & Natural gas, production GB, at long-distance pipeline/RER U & $1.20 \times 10^{-3}$ \\
Qatar & 17 & see LNG model & $2.09 \times 10^{-2}$ \\
Russia & 3 & Natural gas, production RU, at long-distance pipeline/RER U & $2.17 \times 10^{-2}$ \\
Other & 6 & Natural gas, at long-distance pipeline/RER U & $1.03 \times 10^{-2}$ \\
\hline
\end{tabular}

Table 3. Production, transport and evaporation data of $1 \mathrm{MJ}$ of the LNG.

\begin{tabular}{lll}
\hline EcoInvent processes & Amount & Units \\
\hline Production & & \\
\hline Natural gas, at production onshore/DZ U & $2.70 \times 10^{-2}$ & $\mathrm{~m}^{3}$ \\
\hline Liquefaction & & \\
\hline Natural gas, burned in gas motor, for storage/DZ U & $1.56 \times 10^{-1}$ & $\mathrm{MJ}$ \\
Production plant, natural gas/GLO/I U & $2.13 \times 10^{-14}$ & $\mathrm{P}$ \\
\hline Transport & & \\
\hline Transport, liquefied natural gas, freight ship/OCE U & $2.44 \times 10^{-1}$ & $\mathrm{tkm}$ \\
\hline Evaporation & & \\
\hline Water, salt, ocean & $1.73 \times 10^{-5}$ & $\mathrm{~m}$ \\
Natural gas, burned in gas turbine, for compressor station/DZ U & $1.51 \times 10^{-2}$ & $\mathrm{MJ}$ \\
Production plant, natural gas/GLO/I U & $2.13 \times 10^{-14}$ & $\mathrm{P}$ \\
\hline Distribution & & \\
\hline Natural gas, burned in industrial furnace >100kW/RER U & $1.67 \times 10^{-3}$ & $\mathrm{MJ}$ \\
Electricity, medium voltage, at grid/BE U & $7.14 \times 10^{-5}$ & $\mathrm{kWh}$ \\
Pipeline, natural gas, high pressure distribution network/CH/I U & $7.95 \times 10^{-10}$ & $\mathrm{~km}$ \\
Transport, natural gas, pipeline, long distance/RER U & $7.67 \times 10^{-3}$ & $\mathrm{tkm}$ \\
\hline
\end{tabular}

\section{Result: Carbon Footprint of Electricity from Blast Furnace Gas}

The Life Cycle Inventory Assessment (LCIA) can be summarized in Table 4, with the results of the manufacturing of the electricity plant, production of the feedstock and the conversion emissions occurring during the generation of the electricity. The table gives the $\mathrm{CO}_{2}$ eq emissions per produced $\mathrm{kWh}$ for the different life phases of electricity production with BFG and natural gas.

Table 4. Climate change impact $\left(\mathrm{kg} \mathrm{CO} \mathrm{CO}_{2} \mathrm{eq} / \mathrm{kWh}\right)$ of the different life phase of electricity generation from BFG and natural gas.

\begin{tabular}{|c|c|c|}
\hline In kg $\mathrm{CO}_{2} \mathrm{eq} / \mathrm{kWh}$ & BFG & Natural Gas \\
\hline Plant infrastructure $\left(\mathrm{GWP}_{\text {plant }}\right)$ & 0.0004 & 0.0003 \\
\hline Feedstock $\left(\mathrm{GWP}_{\text {feedstock }}\right)$ & 0.112 & 0.050 \\
\hline Conversion $\left(\mathrm{GWP}_{\text {conversion }}\right)$ & 1.102 & 0.358 \\
\hline Total $\left(\mathrm{GWP}_{\text {elec }}\right)$ & 1.215 & 0.408 \\
\hline
\end{tabular}

The "feedstock" and the "conversion" emissions can be allocated with the different rules provided above. First of all, the chosen sets of allocation rules are discussed. The climate change impact is 
expressed as the global warming potential (GWP) with $\mathrm{kg} \mathrm{CO}_{2}$ equivalents as the unit. All emissions relevant for climate change are translated in $\mathrm{kg} \mathrm{CO}_{2}$ equivalents. The impact on climate change of producing electricity will include the feedstock production, the conversion and the production of the plant itself, see Equation (6). The main question is about which allocation factors to consider for the feedstock and the conversion step. To calculate the total impact on climate change of producing electricity, following formula is used:

$$
G W P_{\text {elec } B F G}=G W P_{\text {feedstock }}+G W P_{\text {conversion }}+G W P_{\text {plant }}
$$

where $G W P_{\text {elec, } B F G}$ is the GWP of producing electricity from blast furnace gas; $G W P_{\text {feedstock }}$ is the GWP of the blast furnace process; $G W P_{\text {conversion }}$ is total conversions emissions from the electricity plant; $G W P_{\text {plant }}$ is GWP for the production of the electricity plant.

\subsection{System Expansion}

In the system expansion approach, Equation (7), the impact of generating electricity from BFG is the same as generating electricity from natural gas. The production of the pig iron is credited for offsetting the life cycle emissions that would have occurred when producing electricity from natural gas. The life cycle emissions for electricity generation from natural gas contain the feedstock production, distribution and the conversion emissions when burning the natural gas in an electricity plant, as shown in the third column of Table 4. The impact of generating electricity from BFG is:

$$
\begin{gathered}
G W P_{\text {elec }, B F G}=G W P_{\text {elec }, N G}=G W P_{\text {feedstock }}+G W P_{\text {conversion }}+G W P_{\text {plant }}= \\
0.050+0.358+0.0003=0.408 \mathrm{~kg} \mathrm{CO} 2 \mathrm{eq} / \mathrm{kWh}
\end{gathered}
$$

\subsection{Industry Split up}

In the 'industry split up' allocation set, the feedstock production is entirely allocated to the pig iron production. The BFG is therefore an emission-free feedstock. However, the conversion emissions occurring in the electricity plant are fully allocated to the production of electricity. The inert $\mathrm{CO}_{2}$ that was produced in the blast furnace gas process and that is part of the composition of the BFG, is $100 \%$ allocated to the pig iron production:

$$
\begin{gathered}
G W P_{\text {elec }, B F G}=G W P_{\text {feedstock }}+G W P_{\text {conversion }}+G W P_{\text {plant }}= \\
0+1.102+0.0004=1.102 \mathrm{~kg} \mathrm{CO} \text { eq } / \mathrm{kWh}
\end{gathered}
$$

\subsection{Energetic Allocation}

In the energetic allocation rule the feedstock production is entirely allocated to the pig iron production. The BFG is again, an emission-free feedstock. The conversion emissions are only partially allocated to the production of electricity, based on the chemical reactions and the corresponding energy which is released during the reaction, $72 \%$ of the net conversion emissions are allocated to the electricity generation from $\mathrm{BFG}$ :

$$
\begin{gathered}
G W P_{\text {elec } B F G}=G W P_{\text {feedstock }}+0.72 \times G W P_{\text {conversion }}+G W P_{\text {plant }}= \\
0+0.72 \times 1.102+0.0004=0.794 \mathrm{~kg} \mathrm{CO} 2 \mathrm{eq} / \mathrm{kWh}
\end{gathered}
$$




\subsection{Economic Allocation}

With an economic allocation approach, the feedstock production is divided between the blast furnace process and the electricity production process with an economic allocation rule. Only $2.29 \%$ of the total emissions produced in the blast furnace are taken into account, which is $0.112 \mathrm{~kg} \mathrm{CO} \mathrm{CO}_{2} \mathrm{eqWh}$. The BFG is therefore not anymore an emission-free feedstock. The conversion emissions are partially allocated to the production of electricity, based on the energetic allocation rule:

$$
\begin{gathered}
G W P_{\text {elec }, B F G}=G W P_{\text {feedstock }}+0.72 \times G W P_{\text {conversion }}+G W P_{\text {plant }}= \\
0.112+72 \% \times 1.102+0.0004=0.906 \mathrm{~kg} \mathrm{CO} 2 \mathrm{eq} / \mathrm{kWh}
\end{gathered}
$$

\subsection{Exergetic Allocation}

With the exergetic allocation rule $85 \%$ of the total carbon emissions produced in the blast furnace and the electricity plant are allocated to the pig iron production. Only $15 \%$ of the total emissions are allocated to the electricity production.

The blast furnace emits $1.56 \mathrm{~kg} \mathrm{CO}$ eq/kg pig iron. The production of $3.13 \mathrm{~kg}$ of pig iron corresponds with the amount of BFG needed for $1 \mathrm{kWh}$ and emits a total of $4.88 \mathrm{~kg} \mathrm{CO}_{2}$ eq. The total conversion emissions are $2.12 \mathrm{~kg} \mathrm{CO} / \mathrm{kWh}$, including all the $\mathrm{CO}_{2}$ emissions which enter the electricity plant via the composition of the blast furnace gas: The previous allocation rules these emissions where allocated for $100 \%$ to the blast furnace.

$$
\begin{aligned}
G W P_{\text {elec }, B F G}=15 \% & \times\left(G W P_{\text {blast furnace }}+G W P_{\text {total conversion }}+G W P_{\text {plant }}\right) \\
& =15 \% \times(4.88+2.12+0.0004) \\
& =1.05 \mathrm{~kg} \mathrm{CO} 2 / \mathrm{kWh}
\end{aligned}
$$

\section{Conclusions}

As LCA is a decision support tool, allocation rules should be explicitly addressed in the reporting. The chosen allocation rule will have an impact on the end result. This should be pointed out by the LCA practitioner to the decision makers. A sensitivity assessment using different sets of allocation rules is an indispensable tool for decision makers to assess the possible environmental impact of a multifunctional process. In Figure 5, the average GWP of producing electricity with BFG as a waste gas from the steel industry is shown, under several different scenarios. Five different approaches to deal with the allocation problem are addressed: system expansion, industry split up, energetic allocation, economic allocation and exergetic allocation. The average GWP varies between $0.794 \mathrm{~kg} \mathrm{CO} \mathrm{C}_{2} \mathrm{eq} / \mathrm{kWh}$ (energetic allocation), $0.906 \mathrm{~kg} \mathrm{CO} \mathrm{CO}_{2} \mathrm{eq} / \mathrm{kWh}$ (economic allocation) $1.05 \mathrm{CO}_{2} \mathrm{eq} / \mathrm{kWh}$ (exergetic allocation) and $1.102 \mathrm{~kg} \mathrm{CO}_{2} \mathrm{eq} / \mathrm{kWh}$ (industry split up). The approach, in which the system is expanded to include the avoided use of natural gas, has the lowest average GWP $\left(0.408 \mathrm{~kg} \mathrm{CO}_{2} \mathrm{eq} / \mathrm{kWh}\right)$ as this approach allocated the burden of using BFG to the steel industry. Different allocation procedures assist different decisions. When it comes to taking consequences of a decision into consideration, system expansion is the most appropriate procedure as it includes the environmental impact of the avoided production. In the industry split up and the energetic allocation set, it is considered that BFG is an emission free feedstock at production level. In the economic allocation method the production of the 
feedstock is allocated partly to the electricity production. The industry split up is the allocation rule provided by EU-ETS document [35], this is an easy-to-understand method that separates the different industries. However, it fails to provide insights on the benefits of using a waste gas for electricity generation. Another significant issue is that the electricity producer is obliged to burn the BFG and this obligation is not taken into consideration when calculating the carbon footprint with an industry split up allocation rule. The economic allocation rule provides a better understanding of the environmental impact induced by consumption. Products, such as steel and electricity, are produced to make an economic profit; therefore it makes sense to include an economic perspective when dividing environmental impacts of multifunctional processes. The exergetic allocation provides an approach in which two co-products (pig iron and electricity), with a different functionality, are compared on the same unit. An exergetic allocation is able to evaluate material and energy resource depletion.

Figure 5. Average impact on climate change for the production of $1 \mathrm{kWh}$ with blast furnace gas with the different allocation rules.

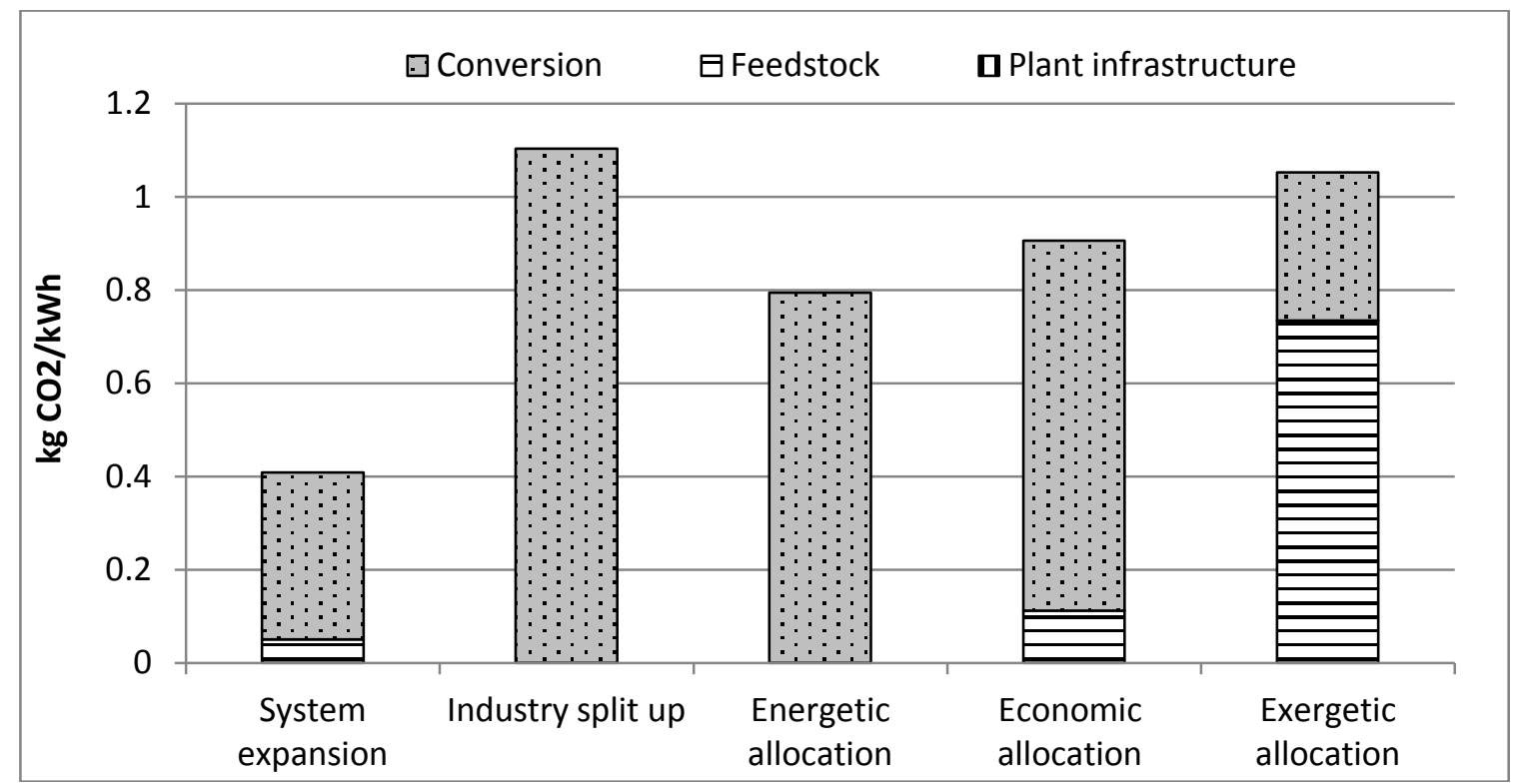

\section{Acknowledgments}

This research has been made partly possible thanks to the support and funding of Electrabel-GDF SUEZ (Belgium). In this framework the carbon footprint has been calculated for the electricity production from blast furnace gas. The project was carried out by Vrije Universiteit Brussel and validated by Laborelec (Belgium) and ESU Services (Switzerland).

\section{References}

1. ISO (International Organization for Standardization). Environmental Management-Life Cycle Assessment-Requirements and Guidelines; ISO 14044:2006; ISO: Geneva, Switzerland, 2006.

2. Ekvall, T.; Tillman, A.-M. Open-loop recycling: Criteria for allocation procedures. Int. J. LCA 1997, 2, 155-162. 
3. Azapagic, A.; Clift, R. Allocation of environmental burdens in multiple-function systems. J. Clean. Prod. 1999, 7, 101-119.

4. Van Mierlo, J.; Maggetto, G.; van de Burgwal, E. Driving style and traffic measures-Influence on vehicle emissions and fuel consumption. J. Automob. Eng. 2004, 218, 43-50.

5. Huppes, G. A general method for allocation in LCA. In Proceedings of the European Workshop on Allocation in LCA, Leiden, The Netherlands, 24-25 February 1994; pp. 74-90.

6. Boguski, T.K.; Hunt, R.G.; Franklin, W.E. General mathematical models for LCI recycling. Res. Conserv. Recycl. 1994, 12, 147-163.

7. Van Mierlo, J.; Timmermans, J.M.; Maggetto, G. Environmental rating of vehicles with different alternative fuels and drive trains: A comparison of two approaches. Transp. Res. Part. D Transport. Environ. 2004, 9, 387-399.

8. Klöpffer, W. Allocation rule for open-loop recycling in life cycle assessment-A review. Int. J. LCA 1996, 1, 27-31.

9. Van Mierlo, J.; Vereecken, L.; Maggetto, G. How to define clean vehicles? Environmental impact rating of vehicles. Int. J. Autom. Technol. 2003, 4, 77-86.

10. Kim, S.; Hwang, T.; Lee, K.M. Allocation for cascade recycling system. Int. J. LCA 1997, 2, 217-222.

11. Newell, S.A.; Field, R.F. Explicit accounting methods for recycling in LCI. Res. Conserv. Recycl. 1998, 22, 31-45.

12. Rydberg, T. Cascade accounting in life cycle assessment applied to polymer recycling. Polym. Recycl. 1995, 1, 233-241.

13. Van Mierlo, J.; Maggetto, G. Innovative iteration algorithm for a vehicle simulation program. Ieee. Trans. Veh. Technol. 2004, 53, 401-412.

14. Bernesson, S.; Nilsson, D.; Hansson, P.-A. A limited LCA comparing large- and small-scale production of ethanol for heavy engines under Swedish conditions. Biomass Bioenergy 2006, 30, 46-57.

15. Huo, H.; Wang, M.; Bloyd, C.; Putsche, V. Life-Cycle assessment of energy use and greenhouse gas emissions of soybean-derived biodiesel and renewable fuels. Environ. Sci. Technol. 2008, 43, 750-756.

16. Balat, H. Prospects of biofuels for a sustainable energy future: A critical assessment. Energy Educ. Sci. Technol. Part. A. 2010, 24, 85-111.

17. Luo, L.; van der Voet, E.; Huppes, G.; Udo de Haes, H. Allocation issues in LCA methodology: A case study of corn stover-based fuel ethanol. Int. J. Life Cycle Assess. 2009, 14, 529-539.

18. Van den Bossch, P.; Vergels, F.; van Mierlo, J. SUBAT: An assessment of sustainable battery technology. J. Power Sources 2006, 162, 913-919.

19. Lam, S.S.; Chase, H.A. A review on waste to energy processes using microwave pyrolysis. Energies 2012, 5, 4209-4232.

20. Sahin, Y. Environmental impacts of biofuels. Energy Educ. Sci. Technol. Part A 2011, 26, 129-142.

21. Malca, J.; Freire, F. Renewability and life-cycle energy efficiency of bioethanol and bio-ethyl tertiary butyl ether (bioETBE): Assessing the implications of allocation. Energy 2006, 31, 3362-3380. 
22. Messineo, A.; Freni, G.; Volpe, R. Collection of thermal energy available from a biogas plant for leachate treatment in an urban landfill: A sicilian case study. Energies 2012, 5, 3753-3767.

23. Shapouri, H.; Duffield, J.A.; Wang, M. The energy balance of corn ethanol: An update. In Agricultural Economic Report 813; US Department of Agriculture: Washington, DC, USA, 2002.

24. Matheys, J.; van Autenboer, W.; Timmermans, J.M.; van Mierlo, J. Influence of functional unit on the life cycle assessment of traction batteries. Int. J. Life Cycle Assess. 2007, 12-13, 191-196.

25. Demirbas, A. Social, economic, environmental and policy aspects of biofuels. Energy Educ. Sci. Technol. Part B 2010, 2, 75-109.

26. Tsai, W.-T. An analysis of the use of biosludge as an energy source and its environmental benefits in Taiwan. Energies 2012, 5, 3064-3073.

27. Cucchiella, F.; D'Adamo, I.; Gastaldi, M. Modeling optimal investments with portfolio analysis in electricity markets. Energy Educ. Sci. Technol. Part A 2012, 30, 673-692.

28. Barrero, R.; van Mierlo, J.; Tackoen, X. Energy savings in public transport. IEEE Vehicular Technol. Mag. 2008, 3, 26-36.

29. Cherubini, F.; Strømman, A.H.; Ulgiati, S. Influence of allocation methods on the environmental performance of biorefinery products-A case study. Res. Conserv. Recycl. 2011, 55, 1070-1077.

30. ISO. Environmental Management-Life Cycle Assessment-Principles and Framework; ISO 14040:2006; ISO: Geneva, Switzerland, 2006.

31. Ekvall, T.; Finnveden, G. Allocation in ISO 14041-A critical review. J. Cleaner Prod. 2001, 9 , 197-208.

32. Finnveden, G.; Ekvall, T. Life-Cycle assessment as a decision-support tool-the case of recycling versus incineration of paper. Res. Conserv. Recycl. 1998, 24, 235-256.

33. Schmidt, W.-P.; Beyer, H.-M. Environmental considerations on battery-housing recovery. Int. J. LCA 1999, 4, 107-112.

34. Ekvall, T.; Person, L.; Ryberg, A.; Widheden, J.; Frees, N.; Nielsen, P.H.; Weidema, B.P.; Wesnæs, M. Life Cycle Assessment of Packaging Systems for Beer and Soft Drinks-Main Report; Danish Environmental Protection Agency: Copenhagen, Denmark, 1998.

35. European Commission. Waste Gases and Process Emissions Sub-Installation. Guidance Document $\mathrm{n}^{\circ} 8$ on the Harmonized Free Allocation Methodology for the EU-ETS Post 2012. Available online: http://ec.europa.eu/clima/policies/ets/benchmarking/docs/gd8_waste_gases_en.pdf (accessed on 26 February 2013).

36. Classen, M.; Althaus, H.-G.; Blaser, S.; Scharnhorst, W.; Tuchschmid, M.; Jungbluth, N.; Faist Emmenegger, M. Life Cycle Inventories of Metals, Ecoinvent V2.1; Report No. 10; Swiss Centre for Life Cycle Inventories: Dubendorf, Switzerland, 2009.

37. Barrington, C. Ore-Based Metallics: Overview of Global Trends; International Iron Metallics Association: London, UK, 2010.

38. Gasparatos, A.; El-Haram, M.; Hroner, M. Assessing the sustainability of the UK society using thermodynamic concepts: Part 2. Renew. Sustain. Energy Rev. 2009, 13, 956-970.

39. Dones, R.; Bauer, C.; Bolliger, R.; Burger, B.; Roder, A.; Faist-Emmenegger, M.; Frischnecht, R.; Jungbluth, N.; Tuchschmid, M. Life Cycle Inventories of Energy Systems: Results for Current Systems in Switzerland and Other UCTE Countries, Villigen and Uster; Ecoinvent Report No 5; Swiss Centre for Life Cycle Inventories: Dubendorf, Switzerland, 2007. 
40. FOD Economy. Energy Market 2009. Available online: http://economie.fgov.be (accessed on 26 February 2013).

(C) 2013 by the authors; licensee MDPI, Basel, Switzerland. This article is an open access article distributed under the terms and conditions of the Creative Commons Attribution license (http://creativecommons.org/licenses/by/3.0/). 